\title{
Measurement of natural killer activity and target cell binding by mouse metrial gland cells isolated by enzymic or mechanical methods
}

\author{
E. L. Parr*, A. Szary† and M. B. Parr* \\ *Department of Anatomy and †Central Hybridoma Laboratory, School of Medicine, \\ Southern Illinois University, Carbondale, Il 62901, USA
}

\begin{abstract}
Summary. Cells of the metrial glands of mice were isolated by enzymic or mechanical dissociation procedures. Morphological observations indicated that up to half of the enzymically dissociated cells and nearly all of the mechanically dissociated cells were granulated metrial gland cells, but the presence of some fibroblast-like stromal cells among the latter population was not ruled out. Moreover, the granulated metrial gland cells had lost a substantial part of their granule content during isolation. Both cell preparations had little or no natural killer (NK) activity, indicating either that granulated metrial gland cells are not NK-like or that their NK activity was impaired by loss of granule-associated lytic substances or by other factors. Enzymically dissociated metrial gland cells did not bind significantly to the NK target cell YAC-1, nor did they develop granules, NK activity, or the ability to bind YAC-1 cells during culture in vitro, either in normal medium or with the addition of indomethacin or lymphokines. Mechanically dissociated metrial gland cells bound avidly to YAC-1 cells but not to P815 cells or adult thymus cells, which are not NK target cells. Since many if not most of the mechanically dissociated metrial gland cells appeared morphologically to be granulated metrial gland cells, their selective binding to an NK target cell suggests that granulated metrial gland cells may be related in some way to NK cells.
\end{abstract}

Keywords: metrial gland; GMG cells; NK activity; mouse

\section{Introduction}

The metrial gland is a region of uterine tissue that develops near the placenta in several species (Bulmer et al., 1987). It consists primarily of two cell types, a conspicuous granulated metrial gland cell and a fibroblast-like stromal cell (Peel \& Bulmer, 1977). The granulated metrial gland cells in mice are $15-50 \mu \mathrm{m}$ in diameter and exhibit numerous glycoprotein-containing granules that averaged $2-3 \mu \mathrm{m}$ in diameter (Peel et al., 1983). Several observations suggest that these cells may be natural killer (NK)-like cells: they have a lymphoid morphology (Peel \& Bulmer, 1977); differentiate in situ from small, lymphocyte-like cells (Smith, 1966; Peel \& Bulmer, 1977; Stewart \& Peel, 1977); originate from bone marrow precursors (Peel et al., 1983; Peel \& Stewart, 1984); express the leucocyte common antigen in rats (Mitchell \& Peel, 1984); morphologically resemble large granular lymphocytes with NK activity (Reynolds et al., 1981; Herberman, 1982; Ortaldo \& Herberman, 1984); contain perforin, a lytic protein of NK cells (Parr et al., 1987); and contain granules (Peel ('t al., 1983) that are ultrastructurally similar to the granules of cloned mouse cell lines that exhibit high NK activity (Born et al., 1983; Podack, 1985; Young et al., 1986). Cells that are morphologically similar to granulated metrial gland cells are present in the human decidua basalis, where they express a surface marker of human NK cells, NKH1, but not several other markers of NK cells 
(Ritson \& Bulmer, 1987). In the present study we describe the isolation of metrial gland cells by enzymic or mechanical methods, morphological characterization of the isolated cells, and the NK lytic and target binding activities of the isolated cells before and after short-term culture in vitro.

\section{Materials and Methods}

Animals. Outbred albino mice of the ICR strain were purchased from SASCO Inc. (Omaha, NE, USA) and used at 10-20 weeks of age. Day 1 of pregnancy denotes the day a seminal plug was found in the vagina.

Enzymic isolation of metrial gland cells. Metrial gland tissue was dissected from all implantation sites of 1 or 2 mice on Days 13-15 of pregnancy, minced coarsely with scissors, suspended in $10 \mathrm{ml}$ phosphate-buffered saline (PBS), and centrifuged. The pellet of minced tissue was resuspended in $6.0 \mathrm{ml}$ of medium consisting of: Hanks' balanced salt solution, $10 \%$ fetal bovine serum, $4 \mathrm{mg}$ collagenase $/ \mathrm{ml}$ (type 1), $2 \mathrm{mg}$ protease IX/ml (dispase), and $10 \mu \mathrm{g} \mathrm{DNAase} / \mathrm{ml}$ (all from Sigma Chemical Co., St Louis, MO, USA). The tissue was digested for $30 \mathrm{~min}$ at $37^{\circ} \mathrm{C}$ with shaking at 300 strokes per min and a stroke length of $15 \mathrm{~mm}$ on a Burrell Wrist Action Shaker. The digested tissue was passed through a metal screen and the dissociated cells were collected by low-speed centrifugation. The cell pellet was resuspended in $1.0 \mathrm{ml}$ PBS containing $30 \mathrm{~mm}$-EDTA, into which was mixed $4.0 \mathrm{ml} 10 \%$ bovine serum albumin (BSA) in PBS at $\mathrm{pH} 7.0$ and $3.0 \mathrm{ml}$ Sepracell ${ }^{\circledR}$ (Sepratech Corp., Tulsa, OK, USA). After layering $2.0 \mathrm{ml}$ PBS over the gradient medium, the cell suspension was centrifuged for $20 \mathrm{~min}$ at $500 \mathrm{~g}$ in a swinging bucket rotor. Low-density cells were collected from the PBS-Sepracell ${ }^{\circledR}$ interface, while erythrocytes and other cells and cell fragments formed a pellet at the bottom. Large, spherical cells containing refractile cytoplasmic organelles that appeared to be granules or vacuoles by phase-contrast microscopy were abundant in the low density band but were not present elsewhere in the gradient. The low-density cells were diluted with a larger volume of PBS- $0 \cdot 10 \%$ BSA and collected by centrifugation. The cell isolation procedure was done at $22^{\circ} \mathrm{C}$ except for the enzyme digestion, and required about $2 \mathrm{~h}$.

Mechanical isolation of metrial gland cells. Metrial glands from 2 donors on Days 13-15 of pregnancy were teased into small fragments with curved dental picks in Medium RPMI 1640 (Grand Island Biologicals, Grand Island, NY, USA) plus $10 \%$ fetal bovine serum (RF10). The tissue fragments were pipetted to release cells, which were then passed through a metal screen and collected by low-speed centrifugation. The pellet was resuspended in $1 \mathrm{ml}$ Medium RF 10 and in most experiments was layered over $5 \mathrm{ml}$ of a mixture of Histopaque ${ }^{\circledR} 1119$ (Sigma) and fetal bovine serum in various proportions (Table 2). In two experiments the cell suspension was first layered over $5 \mathrm{ml}$ fetal bovine serum and centrifuged at $200 \mathrm{~g}$ for $10 \mathrm{~min}$; the pellet was then resuspended and layered over the Histopaque ${ }^{\circledR} 1119$-fetal bovine serum mixture. The gradient medium was centrifuged at $200 \mathrm{~g}$ for $15 \mathrm{~min}$ and the cells at the Medium RF10-Histopaque ${ }^{\circledR} 1119$ interface were collected, mixed with $5 \mathrm{ml}$ Medium RF10, centrifuged at low speed, and resuspended in Medium RF10. The interface contained mainly viable, large, spherical cells with refractile cytoplasmic organelles; a variable amount of cell fragments was also present. The erythrocytes, dead cells, free nuclei, and most of the cell fragments passed to the bottom of the tube. Nearly all of the large, spherical cells were present at the interface when $70 \%$ and $50 \%$ Histopaque ${ }^{\circledR} 1119$ were used, but up to half of these cells were present in the pellet at the bottom of the tube when $45 \%$ and $40 \%$ Histopaque ${ }^{\circledR} 1119$ were used (Table 2). However, with $45 \%$ and $40 \%$ Histopaque ${ }^{\circledR}$ 1119 the large, spherical cells at the interface were relatively free of contaminating cell fragments (Fig. 2). The isolation procedure was done at $22^{\circ} \mathrm{C}$ and required about $2 \mathrm{~h}$.

Histological methods. The viability of isolated cells was tested by exclusion of $0 \cdot 10 \%$ Trypan blue in PBS. Smears were prepared from the isolated cells, air dried, and fixed in one of the following ways: $100 \%$ acetone for $10 \mathrm{~min}$, Bouin's fixative or buffered $4 \%$ formaldehyde for $1 \mathrm{~h}, 2.5 \%$ glutaraldehyde in $0.10 \mathrm{M}$-cacodylate buffer for $1 \mathrm{~h}, 1.0 \%$ osmium tetroxide in distilled water for $1 \mathrm{~h}$, or formaldehyde vapour overnight. All cytosmears were stained by the periodic acid-Shiff (PAS) method and counterstained with haematoxylin. Intact metrial glands on Day 13 and metrial gland cells isolated by the enzymic method and collected by centrifugation were fixed for $2 \mathrm{~h}$ in $2.5 \%$ glutaraldehyde in 0.10 M-cacodylate buffer, dehydrated in ethanol, and then embedded in JB-4 resin (Polysciences, Inc., Warrington, PA, USA). Metrial gland cells isolated by the mechanical method were prepared similarly except that they were first mixed with isolated thymocytes to make the cell pellet larger and easier to handle. Sections $(2 \mu \mathrm{m})$ of cell pellets and intact metrial glands were stained by the PAS method and counterstained by haematoxylin or methylene blue.

In-vitro culture of enzymically dissociated metrial gland cells. Approximately $10^{6}$ enzyme-dissociated metrial gland cells were cultured in vitro for $24 \mathrm{~h}$ or $72 \mathrm{~h}$ in $5 \mathrm{ml}$ Medium RF10 supplemented with $100 \mathrm{U}$ penicillin/ml, $100 \mu \mathrm{g}$ streptomycin $/ \mathrm{ml}, 0.25 \mu \mathrm{g}$ amphotericin $/ \mathrm{ml}, 300 \mu \mathrm{g}$ L-glutamine $/ \mathrm{ml}$, non-essential amino acids (M. A. Bioproducts, Walkersville, MD, USA) and $200 \mathrm{ng}$ progesterone $/ \mathrm{ml}$ (Adam \& Peel, 1983) in $50 \mathrm{ml}$ culture flasks. This medium, except for progesterone, is commonly used to maintain mouse NK cells in vitro (Wiltrout et al., 1984). Indomethacin was added to some cultures at $10^{-6} \mathrm{M}$ to inhibit prostaglandin synthesis (Matthews \& Searle, 1986). A lymphokineenriched medium was prepared by culturing mouse spleen cells for $48 \mathrm{~h}$ in a mitogenic dose of concanavalin A (Sigma) in the complete medium described above supplemented with $5 \times 10^{-5} \mathrm{M}-2$-mercaptoethanol, but lacking progesterone and indomethacin (Watson et al., 1979). Residual lectin was removed from the medium by absorption on Sephadex ${ }^{\circledR}$ G-25 beads. 
NK activity. A ${ }^{51} \mathrm{Cr}$-release cytotoxicity assay was used to determine the NK activity of metrial gland cells and spleen cells against YAC-1, P815 and normal thymus target cells. The target cells were labelled with ${ }^{51} \mathrm{Cr}$ by the method of Wiltrout et al. (1984). Briefly, $5 \times 10^{6}$ target cells in $0.5 \mathrm{ml}$ Medium RF10 were mixed with $0 \cdot 10 \mathrm{mCi}{ }^{51} \mathrm{Cr}$ (Amersham, Arlington Heights, IL, USA) and incubated in $5 \% \mathrm{CO}_{2}$ at $37^{\circ} \mathrm{C}$ for $1 \mathrm{~h}$. Labelled cells were washed 3 times in Medium RF10 before use. The cytotoxicity assay was also performed as described by Wiltrout et al. (1984). In most cases $1.0 \times 10^{4}{ }^{51} \mathrm{Cr}$-labelled target cells $(100 \mu \mathrm{l})$ were incubated in quadruplicate with $100 \mu \mathrm{l}$ of effector cells in Medium RF10 in V-bottom microtitre plates (Costar Corp., Cambridge, MA, USA) in $5 \% \mathrm{CO}_{2}$ for $4 \mathrm{~h}$ at $37^{\circ} \mathrm{C}$. To increase the effector:target cell ratio when mechanically dissociated metrial gland cells were used as effectors, the assays were done in triplicate and only $5 \times 10^{3}$ labelled target cells were used. After incubation the plates were centrifuged at $200 \mathrm{~g}$ for $5 \mathrm{~min}$ and supernatant radioactivity was measured in a gamma counier. NK activity is expressed as percentage specific lysis by the formula:

$$
\% \text { specific lysis }=\frac{\mathrm{ER}-\mathrm{SR}}{\mathrm{MR}-\mathrm{SR}} \times 100 \%
$$

where ER represents isotope release in experiment wells, $\mathrm{SR}$ is spontaneous isotope release in wells lacking effector cells, and MR is maximal isotope release from target cells treated with $1 \%$ Nonidet P-40 detergent.

When isolated metrial gland cells were cultured in vitro the large, spherical cells remained non-adherent or only lightly adherent to the flasks, but a population of adherent cells was present. The NK activity of the adherent cells was determined as foilows. The medium $(5.0 \mathrm{ml})$ and non-adherent cells were drained from $50 \mathrm{ml}$ culture flasks and $1.0 \times 10^{5}$ labelled YAC-1 target cells in $1.0 \mathrm{ml}$ Medium RF10 were introduced and incubated for $4 \mathrm{~h}$. The medium was then recovered, the target cells were removed by centrifugation, and $0.1 \mathrm{ml}$ of the supernatant was counted in a gamma counter. Spontaneous lysis was determined using flasks without adherent cells, and maximal release was determined by counting $0.1 \mathrm{ml}$ of supernatant after detergent lysis and centrifugation of target cells recovered from flasks without adherent cells.

The significance of NK activities of metrial gland cells was estimated by comparing them to measurements of spleen NK activity against P815 target cells. The latter cells showed chromium uptake and spontaneous release values similar to those of YAC-1 cells, but they were refractory to NK lysis (Wigzell \& Ramstedt, 1986; Table 3). Thus, if NK activities by metrial gland effectors against YAC-1 target cells were within the range of activities seen with spleen effectors against P815 target cells, they were considered to be not significantly different from zero.

Binding of metrial gland cells to YAC-1, P815 and thymus cells. The single-cell cytotoxicity assay described by Reynolds et al. (1981) was adapted for these experiments. Metrial gland cells isolated by the enzymic or mechanical method (using $40 \%$ Histopaque $\left.{ }^{\circledR} 1119\right)$ were mixed with test cells at a ratio of 1:10 in Medium RF10. The test cells used were YAC-1, P815 and normal thymus cells from 10-12-week-old female donors. The cell mixtures were incubated for $5 \mathrm{~min}$ at $29^{\circ} \mathrm{C}$, centrifuged at $200 \mathrm{~g}$ for $10 \mathrm{~min}$ at room temperature, and then incubated at $37^{\circ} \mathrm{C}$ for $15 \mathrm{~min}$. The cell pellet was resuspended in $0.2 \mathrm{ml}$ by 10 gentle pipettings with a Pasteur pipette and examined by phasecontrast microscopy. The large, spherical metrial gland cells were distinguishable from test cells by their large size and refractile cytoplasmic organelles. Binding was assessed in terms of the proportion of large spherical cells bound to test cells, by the presence of cell aggregates containing both cell types, and by the size of the aggregates.

Single-cell cytotoxicity assay in agarose. This assay was performed as described by Reynolds et al. (1981). Briefly, equal numbers of YAC-1 cells and mechanically dissociated metrial gland cells (using 40\% Histopaque ${ }^{\circledR} 1119$ ) were mixed, incubated $5 \mathrm{~min}$ at $29^{\circ} \mathrm{C}$, pelleted by centrifugation at $200 \mathrm{~g}$ for $5 \mathrm{~min}$, incubated for $15 \mathrm{~min}$ at $37^{\circ} \mathrm{C}$, resuspended in $0.2 \mathrm{ml}$ medium by 10 pipettings with a Pasteur pipette, mixed with $1.0 \mathrm{ml}$ of $1.0 \%$ Sea-Plaque ${ }^{\circledR}$ agarose (FMC Bioproducts, Rockland, ME, USA) at $37^{\circ} \mathrm{C}$, poured into a plastic Petri dish, cooled, covered with Medium $\mathrm{RF} 10$, and incubated at $37^{\circ} \mathrm{C}$ for $4 \mathrm{~h}$. To detect dead cells the agarose layers were stained for $10 \mathrm{~min}$ with $0 \cdot 10 \%$ Trypan blue in PBS, washed, and examined in an inverted microscope. Conjugates between YAC-I cells and viable, large, spherical cells were observed, and the number of dead YAC-1 cells in 50 such conjugates was recorded. Subsequently, the cells in agarose were fixed overnight in buffered $4 \%$ formaldehyde and stained by the PAS method to confirm that the large, spherical cells in the conjugates contained PAS-positive granules and/or diffuse cytoplasmic PAS staining.

\section{Results}

\section{Identification of cells isolated by the enzymic method}

Metrial gland cells obtained by enzymic dissociation were examined by phase-contrast microscopy and in cytosmears and sectioned cell pellets. By phase-contrast microscopy about half of the cells were large ( $20-40 \mu \mathrm{m}$ in diameter), spherical, and contained refractile cytoplasmic organelles that appeared to be either granules or vacuoles. The viability of these cells exceeded $95 \%$, and their yield averaged $2 \times 10^{5}$ per metrial gland on Day 13 or 14 of pregnancy. In cytosmears the large, spherical cells rarely contained PAS-positive granules with any of the fixatives used; instead, 
they contained many unstained vacuoles, $1-3 \mu \mathrm{m}$ in diameter. Sections of cell pellets showed that about half of the isolated cells were large and spherical, and contained 1 or 2 oval nuclei with large nucleoli and a thin peripheral rim of heterochromatin. The cytoplasm of these cells showed diffuse PAS staining and often contained a few PAS-positive granules typical of those present in granulated metrial gland cells but less numerous. Many vacuoles were also present that were in the same size range as the granules in granulated metrial gland cells. The vacuoles often contained small PAS-positive granules (Fig. 1). A comparison of the isolated, large, spherical cells to granulated metrial gland cells in situ, taking into account their size and shape, the morphology and PAS staining of the granules, nuclear and nucleolar morphology, nuclear/cytoplasmic ratio, the incidence of binucleate cells, diffuse cytoplasmic PAS staining, the correspondence between the number and size of vacuoles in the isolated cells and granules in granulated metrial gland cells, and especially the presence of small PAS-positive granules within many of the vacuoles, suggested that most of the isolated, large, spherical cells were granulated metrial gland cells that had lost PASpositive material from their granules during isolation. The possibility that some of these cells were fibroblast-like stromal cells from the metrial gland cannot be excluded because this cell type may also contain vacuoles. In cytosmears made from crude cell suspensions before fractionation on Sepracell ${ }^{\circledR}$, the large spherical cells contained vacuoles rather than granules, suggesting that loss of granule content had already occurred at the stage. Other cell types identifiable in the sectioned cell pellets included fetal erythrocytes surrounded by squamous cells, uterine epithelial cells, rare trophoblast giant cells, and occasional granulated metrial gland cells with a normal complement of granules.

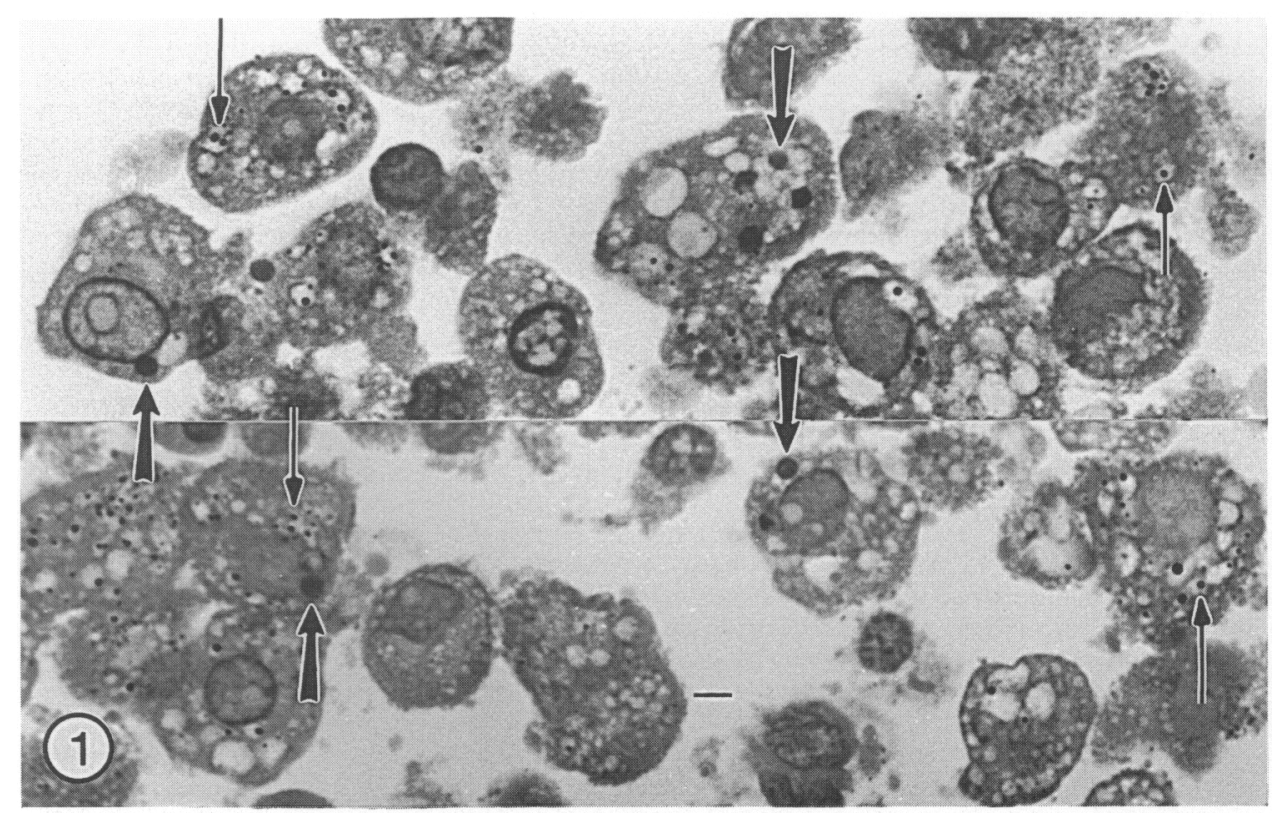

Fig. 1. A montage showing two regions of a PAS-stained section from a glutaraldehyde-fixed pellet of enzymically dissociated metrial gland cells. Most of the cells appear to belong to a distinctive population whose cells are large $(\sim 30 \mu \mathrm{m}$ in diameter) and spherical, often contain one or a few PAS-positive cytoplasmic granules typical of those present in granulated metrial gland cells (large arrows), contain many cytoplasmic vacuoles that correspond in size and number to metrial gland cell granules and which often contain small PAS-positive granules (small arrows), and contain oval nuclei with prominent nucleoli and only a thin rim of peripheral heterochromatin. The nucleoli are unstained because haematoxylin was used as the counterstain. $\times 670$. 


\section{NK activity of enzymically dissociated metrial gland cells and effects of culture in vitro}

Enzymically dissociated metrial gland cells exhibited little or no NK activity when tested immediately after isolation (Table 1). The assay detected typical levels of NK activity by spleen cells (Table 3). After $24 \mathrm{~h}$ culture in vitro an average of only $43 \%$ of the large, spherical cells originally placed in culture were recovered, and the cells did not have NK activity (Table 1). The addition of indomethacin to the culture medium to inhibit prostaglandin synthesis had no effect on the recovery of large, spherical cells or their NK activity. The cultured, large, spherical cells were unattached or only lightly attached to the culture flask, but a population of adherent cells was present. Separate measurements using the adherent or non-adherent cells as effectors indicated that neither had NK activity (Table 1). This suggested that the adherent cells were not responsible for the lack of NK activity by the non-adherent cells. Cytosmears indicated that there was no increase in the number of PAS-positive granules in the cultured, large, spherical cells, including those cultured with indomethacin.

Table 1. Effects of culture in vitro, indomethacin, and lymphokines on the viability and NK activity of enzymically dissociated metrial gland cells of mice

\begin{tabular}{|c|c|c|c|c|c|c|}
\hline \multirow[b]{2}{*}{ Cells } & \multirow[b]{2}{*}{$\begin{array}{l}\text { Culture } \\
\text { medium* }\end{array}$} & \multirow{2}{*}{$\begin{array}{l}\text { Recovery of } \\
\text { large spherical } \\
\text { cells } \dagger\end{array}$} & \multirow[b]{2}{*}{$\begin{array}{c}\text { E:T } \\
\text { ratio } \neq\end{array}$} & \multicolumn{3}{|c|}{ NK activity $(\%) \S$} \\
\hline & & & & Total & $\begin{array}{c}\text { Non- } \\
\text { adherent }\end{array}$ & Adherent \\
\hline $\begin{array}{l}\text { Fresh } \\
\text { Fresh } \\
\text { Fresh }\end{array}$ & & & $\begin{array}{r}23: 1 \\
97: 1 \\
120: 1\end{array}$ & $\begin{array}{c}1.2 \\
-0.38 \\
3.6\end{array}$ & & \\
\hline $\begin{array}{l}\text { Cultured } \\
24 \mathrm{~h}\end{array}$ & $\begin{array}{l}\text { Normal } \\
\text { Indomethacin }\end{array}$ & $\begin{array}{l}60 \% \\
59 \%\end{array}$ & $\begin{array}{l}28: 1 \\
21: 1\end{array}$ & $\begin{array}{r}-0.14 \\
0.79\end{array}$ & & \\
\hline $\begin{array}{l}\text { Cultured } \\
24 \mathrm{~h}\end{array}$ & $\begin{array}{l}\text { Normal } \\
\text { Indomethacin }\end{array}$ & $\begin{array}{l}30 \% \\
33 \%\end{array}$ & $\begin{array}{l}25: 1 \\
12: 1\end{array}$ & $\begin{array}{r}-0.24 \\
0.08\end{array}$ & & \\
\hline $\begin{array}{l}\text { Cultured } \\
24 \mathrm{~h}\end{array}$ & $\begin{array}{l}\text { Normal } \\
\text { Indomethacin }\end{array}$ & $\begin{array}{l}39 \% \\
44 \%\end{array}$ & $\begin{array}{l}14: 1 \\
12: 1\end{array}$ & $\begin{array}{l}0.56 \\
0.01\end{array}$ & & \\
\hline $\begin{array}{l}\text { Cultured } \\
24 \mathrm{~h}\end{array}$ & $\begin{array}{l}\text { Normal } \\
\text { Indomethacin }\end{array}$ & N.D. & $\begin{array}{l}36: 1 \\
40: 1\end{array}$ & & $\begin{array}{r}0.16 \\
-0.82\end{array}$ & $\begin{array}{l}-1 \cdot 15 \\
-0 \cdot 18\end{array}$ \\
\hline $\begin{array}{l}\text { Cultured } \\
24 \mathrm{~h}\end{array}$ & $\begin{array}{l}\text { Normal } \\
\text { Indomethacin }\end{array}$ & N.D. & $\begin{array}{l}13: 1 \\
14: 1\end{array}$ & & $\begin{array}{l}-0.46 \\
-1.86\end{array}$ & $\begin{array}{l}-1.71 \\
-0.56\end{array}$ \\
\hline $\begin{array}{l}\text { Cultured } \\
24 \mathrm{~h}\end{array}$ & $\begin{array}{l}\text { Normal } \\
\text { Indomethacin }\end{array}$ & N.D. & $\begin{array}{l}10: 1 \\
11: 1\end{array}$ & & $\begin{array}{l}-0.98 \\
-0.23\end{array}$ & $\begin{array}{l}-1 \cdot 75 \\
-2 \cdot 20\end{array}$ \\
\hline $\begin{array}{l}\text { Cultured } \\
72 \mathrm{~h}\end{array}$ & $\begin{array}{l}\text { Normal } \\
\text { Lymphokines }\end{array}$ & $\begin{array}{l}26 \% \\
26 \%\end{array}$ & $\begin{array}{l}12: 1 \\
12: 1\end{array}$ & $\begin{array}{c}1 \cdot 3 \\
-0.16\end{array}$ & & \\
\hline $\begin{array}{l}\text { Cultured } \\
72 \mathrm{~h}\end{array}$ & $\begin{array}{l}\text { Normal } \\
\text { Lymphokines }\end{array}$ & $\begin{array}{l}29 \% \\
37 \%\end{array}$ & N.D. & N.D. & & \\
\hline
\end{tabular}

*Six preparations of enzymically dissociated cells were divided equally and cultured for $24 \mathrm{~h}$ in normal medium or in a medium containing indomethacin at $10^{-6} \mathrm{M}$ to inhibit prostaglandin synthesis. Two additional cell preparations were divided and cultured for $72 \mathrm{~h}$ in normal or lymphokine-containing medium.

+Number of viable, large, spherical cells in the preparations after culture relative to the number originally introduced.

${ }_{4}^{\dagger}$ Effector:target cell ratio based on the number of viable, large spherical cells present.

§The NK activity of spleen effector cells against YAC-1 target cells was readily detectable (Table 3).

Two preparations of metrial gland cells were divided equally and cultured for $72 \mathrm{~h}$ in normal medium or with the addition of an equal volume of lymphokine-containing medium from Con A-stimulated spleen cells. In both preparations there was a further decline in the recovery of large 
spherical cells, and lymphokines did not significantly improve the recovery. Cytosmears demonstrated an absence of PAS-positive granules in the cultured, large, spherical cells, but many unstained vacuoles that were larger than those observed in freshly isolated cells were present. There was no NK activity by the cultured cells, either in normal or lymphokine-enriched medium (Table 1).

\section{Binding of enzyme-dissociated metrial gland cells to Y AC-1}

Fewer than $25 \%$ of enzymically dissociated, large, spherical cells bound to the NK target cell YAC-1 before culture in vitro, after $24 \mathrm{~h}$, or after $72 \mathrm{~h}$ of culture. In the binding assay, most large, spherical cells remained free or were bound to similar cells, and no aggregates of such cells with YAC-1 cells were observed.

\section{Identification of cells isolated by the mechanical method}

All cells obtained by mechanical dissociation of metrial glands were morphologically similar to the large spherical cells obtained by enzymic dissociation, including the presence of small PASpositive granules within many of the vacuoles (Fig. 2), and comparison to granulated metrial gland cells in situ again indicated that most of the isolated cells were granulated metrial gland cells that had lost PAS-positive material from their granules during isolation. It is again possible that some of the isolated cells were fibroblast-like stromal cells containing large vacuoles. The viability of the isolated cells exceeded $95 \%$ and the yield averaged $5 \times 10^{4}$ cells from 20 metrial glands on Day 13 or 14 of pregnancy. No other cell types were detected. In cytosmears made from crude cell suspensions before fractionation on Histopaque ${ }^{\circledR}$, the large, spherical cells contained vacuoles rather than granules, suggesting that loss of granule content had already occurred at that stage.

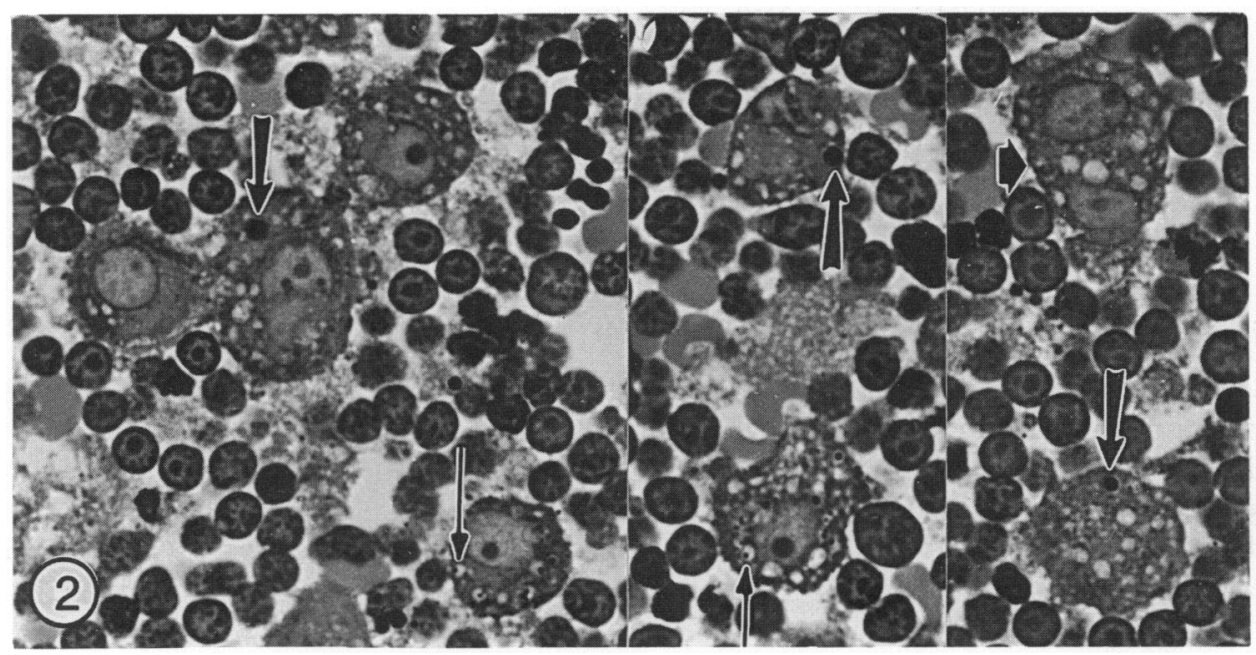

Fig. 2. A montage showing three regions of a PAS-stained section from a glutaraldehyde-fixed pellet of mechanically dissociated metrial gland cells. The cells were mixed with thymocytes (smaller cells) to make the cell pellet large enough to process for microscopy. The large cells are similar to those shown in Fig. 1 except that the nucleoli are better stained by methylene blue. A few large PAS-positive granules typical of those found in granulated metrial gland cells are present (large arrows), along with numerous smaller PAS-positive granules within cytoplasmic vacuoles (small arrows). One of the cells is binucleate (arrowhead). $\times 670$. 


\section{NK activity of mechanically dissociated metrial gland cells}

Mechanically dissociated metrial gland cells had little or no activity (Table 2). Two preparations of cells (Exps 1 and 2) showed no activity, while two others (Exps 3 and 4) exerted a low level of cytotoxicity. Since the mechanically dissociated cell preparations appeared to be mainly purified granulated metrial gland cells, the ratios for granulated metrial gland:YAC-1 cells were high in comparison to typical spleen effector:target ratios, for which only about $2 \%$ of spleen cells are NK cells (Burton et al., 1988). Examination of cytosmears indicated that preparations 3 and 4 contained fewer broken cell fragments than the other two preparations. Cell fragments, especially if they originated from lysed NK cells, could block NK activity by the remaining viable cells. Cells that were relatively free of cell fragments were obtained by centrifugation through a layer of fetal bovine serum before collection from the Medium RF10-40\% Histopaque ${ }^{\circledR}$ interface. These cells did not exhibit NK activity (Exps 5 and 6), but we were not able to achieve effector:target ratios as high as those of Exps 3 and 4.

Table 2. NK activity of mechanically dissociated metrial gland cells of mice

\begin{tabular}{|c|c|c|c|}
\hline Exp. & Purification* & $\begin{array}{c}\text { E:T } \\
\text { ratio }\end{array}$ & $\begin{array}{c}\text { NK activity } \\
(\%) \ddagger\end{array}$ \\
\hline 1 & $70 \%$ Histopaque ${ }^{\circledR}$ & $6 \cdot 5: 1$ & 0.00 \\
\hline 2 & $50 \%$ Histopaque & $6 \cdot 3: 1$ & 0.77 \\
\hline 3 & $45 \%$ Histopaque & $6 \cdot 5: 1$ & $3 \cdot 6$ \\
\hline 4 & $40 \%$ Histopaque & $11: 1$ & $5 \cdot 3$ \\
\hline \multirow[t]{3}{*}{5} & \multirow[t]{3}{*}{ FBS plus $40 \%$ Histopaque } & $\mathrm{I}: 1$ & 0.78 \\
\hline & & $1: 4$ & 0.57 \\
\hline & & $1: 16$ & 0.93 \\
\hline \multirow[t]{3}{*}{6} & \multirow[t]{3}{*}{ FBS plus $40 \%$ Histopaque } & $2: 1$ & 0.45 \\
\hline & & $1: 2$ & 0.06 \\
\hline & & $\mathrm{I}: 8$ & $0 \cdot 00$ \\
\hline
\end{tabular}

*See 'Materials and Methods' for details.

†Effector:target cell ratio based on the number of viable metrial gland cells present.

†The activities in Exps 3 and 4 are marginally higher than the normal range of variation around zero in measurements of spleen NK activity against the non-susceptible target cell P815 $(-1 \cdot 7 \%$ to $+1 \cdot 1 \%$, Table 3 ).

\section{Binding of mechanically dissociated metrial gland cells to YAC-1}

Essentially all mechanically dissociated metrial gland cells bound to the NK target cell YAC-1, forming aggregates containing both cell types and leaving negligible numbers of unbound metrial gland cells (Fig. 3; Table 3). The cellular aggregates were variable in size, and were not in the form of typical rosettes, with one cell type at the centre surrounded by the other cell type. The metrial gland cells did not bind to adult thymus cells or P815 cells, neither of which is susceptible to killing by mouse NK cells (Fig. 3; Table 3).

\section{Single cell cytotoxicity assay}

Conjugates between mechanically dissociated metrial gland cells and YAC-1 cells were readily formed in a single-cell cytotoxicity assay in agarose, but the target cells were not killed. The numbers of dead YAC- 1 cells in 50 conjugates with viable metrial gland cells were 0 and 1 in two experiments. This was not greater than the incidence of spontaneously dead YAC-1 cells in control plates lacking effector cells. 

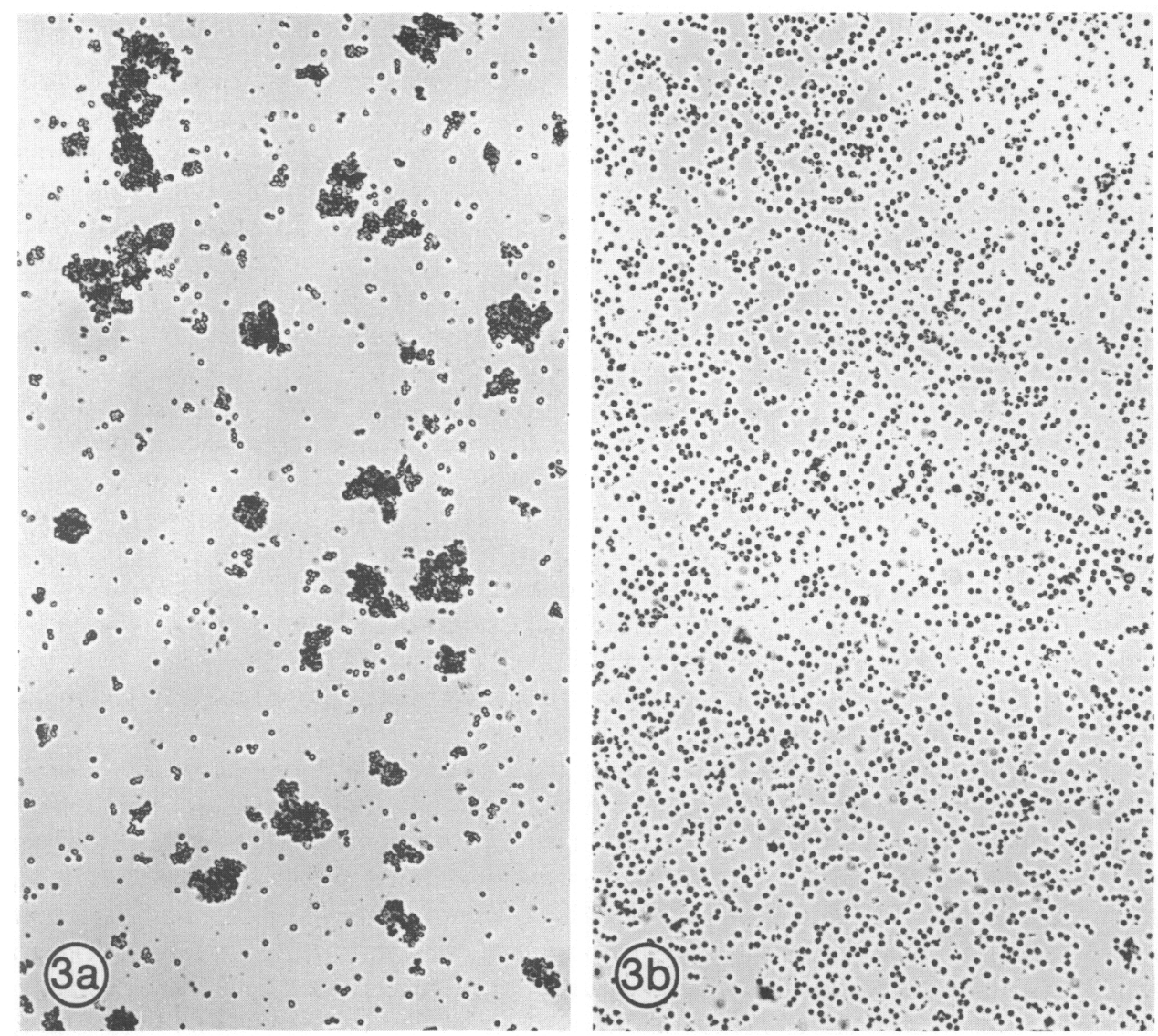

Fig. 3. Binding of mechanically isolated metrial gland cells to YAC-1 cells (a) or P815 cells (b). Binding to YAC-1 cells is evident, but the small aggregates seen in (b) contain only metrial gland cells. Mixtures of metrial gland cells with normal thymus cells looked much like (b), as did suspensions of YAC-1 cells alone. Unstained cells in suspension, $\times 40$.

Table 3. Binding of mechanically dissociated metrial gland cells of mice to target cells that are susceptible or resistant to NK lysis by spleen cells

\begin{tabular}{|c|c|c|c|c|c|c|c|}
\hline \multirow{2}{*}{$\begin{array}{l}\text { Target } \\
\text { cells }\end{array}$} & \multirow{2}{*}{$\begin{array}{l}\text { Binding to metrial gland } \\
\text { cells }(\%)^{*}\end{array}$} & \multicolumn{6}{|c|}{ NK lysis by spleen cells $\dagger$} \\
\hline & & 100:1 & $50: 1$ & $25: 1$ & $12 \cdot 5: 1$ & $6 \cdot 2: 1$ & $3 \cdot 1: 1$ \\
\hline YAC-1 & $100,100,100,100,100,100$ & 13.8 & $9 \cdot 0$ & 5.9 & $4 \cdot 1$ & $2 \cdot 2$ & 1.4 \\
\hline Thymus & $<10,<10,<10$ & $-0 \cdot 2$ & 0.7 & 0.5 & $-3 \cdot 4$ & 1.8 & $1 \cdot 6$ \\
\hline P815 & $<10,<10,<10$ & -0.6 & $-0 \cdot 3$ & $-0 \cdot 2$ & $0 \cdot 1$ & $0 \cdot 2$ & 0.5 \\
\hline
\end{tabular}

*Six preparations of mechanically dissociated cells were divided equally; half were mixed with YAC-1 cells and half were mixed with an equal number of thymus cells or P815 cells as described in the 'Materials and Methods'. The values indicate the $\%$ of metrial gland cells that were bound to target cells.

†Spleen cell effectors were from 6-8-week-old male donors, 2 spleens pooled for each measurement, means of 2 or 3 quadruplicate measurements. 


\section{Discussion}

Dissociation of mouse metrial glands by enzymic or mechanical procedures yielded populations of large spherical cells that resembled granulated metrial gland cells in situ in that they exhibited 1 or 2 oval nuclei, large nucleoli, a thin rim of peripheral heterochromatin, a small nuclear/cytoplasmic ratio, and diffuse cytoplasmic PAS staining. However, the isolated cells contained only a few PASpositive granules typical of those present in granulated metrial gland cells. Instead, they contained mainly vacuoles that corresponded in size and number to the granules of granulated metrial gland cells. These vacuoles of ten contained small PAS-positive granules. Because of the overall morphological similarity of the isolated, large, spherical cells to granulated metrial gland cells, the presence of a few typical granules, and the difficulty in accounting for the small, PAS-positive granules within the vacuoles of the isolated cells other than by partial loss of granule content from granulated metrial gland cells, we conclude that most of the isolated, large, spherical cells were granulated metrial gland cells that lost granule content during isolation. However, some of the large spherical cells could have been fibroblast-like stromal cells because this cell type may normally contain vacuoles. The identification of isolated granulated metrial gland cells of mice at present is limited to morphological characteristics. Specific cell surface markers for these cells have not yet been identified. In rats, granulated metrial gland cells but not other metrial gland cells have been reported to express leucocyte common antigen (Mitchell \& Peel, 1984), and it would be of interest to determine whether this antigen could be used as a specific marker for mouse granulated metrial gland cells.

Vacuolated cells similar to those described in the present report were previously observed in cell preparations obtained by collagenase digestion of rat metrial glands (Bray et al., 1978). The vacuolated cells expressed Fc receptors, whereas a smaller number of normally granulated metrial gland cells in the preparations did not. The identity of the vacuolated cells was not established, but it was suggested that they were probably fibroblast-like stromal cells. Since we found that the vacuolated cells in preparations of dissociated mouse metrial gland appeared to be mainly degranulated metrial gland cells, the identity of the vacuolated rat metrial gland cells is questionable and the possibility that rat granulated metrial gland cells express $\mathrm{Fc}$ receptors should be re-examined. The need to re-examine this issue is further indicated by the report of Daki et al. (1988), who found that $\mathrm{Fc}$ receptors were present on the granulated metrial gland cells and fibroblast-like stromal cells in mice. It is not clear why a few isolated granulated metrial gland cells remained normally granulated while most were degranulated in the present study and possibly also in that of Bray et al. (1978), nor is it clear why, if the vacuolated rat cells were granulated metrial gland cells, they would express $\mathrm{Fc}$ receptors while normally granulated ones did not. In our preparations some granulated metrial gland cells with normal granulation had fragmented nuclei, indicating that they were dead or dying at the time of isolation. This or similar factors could have influenced both degranulation and $\mathrm{Fc}$ receptor expression.

Rat and mouse granulated metrial gland cells are morphologically heterogeneous and are thought to differentiate in situ (Smith, 1966; Peel \& Bulmer, 1977; Stewart \& Peel, 1977). The earliest cells in the sequence are relatively small, have irregularly shaped nuclei with considerable heterochromatin, and have relatively few granules, while the more mature cells in the sequence are larger, have euchromatic nuclei with only thin rims of peripheral heterochromatin, and have larger numbers of granules. The isolated, large, spherical cells described in the present study correspond to the large, more mature granulated metrial gland cells, and are probably a subpopulation of these cells. This may be due to the fact that our fractionation procedures selected the cells of lowest density in the preparations, which were the large cells with low nuclear/cytoplasmic ratios. Moreover, only a small fraction of the granulated metrial gland cells present in tissue were recovered by the mechanical dissociation procedure. This and the selection of low density cells could have caused a restriction of the functional activities of the isolated cells in comparison to the parent population in vivo. 
Enzymically and mechanically dissociated metrial gland cells had little or no NK activity. This may indicate that granulated metrial gland cells are not NK-like, or it could be due to the presence of suppressor cells in the preparations or to selective isolation of inactive cells. It could also be due to loss of granule contents from granulated cells during isolation. There is evidence that the cytotoxicity of NK cells involves their granules (Young \& Cohn, 1986), and our observations indicate that most granulated metrial gland cells in the dissociated cell preparations were severely degranulated. Croy \& Kassouf (1989) have attemptei to detect NK activity in metrial gland by incubating tissue explants with YAC-1 target cells. There was no target cell lysis in such cultures, but control cultures involving spleen tissue explants did show NK activity. Normally granulated metrial gland cells migrated out of metrial gland explants in culture (Mukhtar \& Stewart, 1988) and might thus be expected to come into contact with YAC- 1 cells in co-culture, but this migration was dependent on stage of pregnancy and perhaps other factors and was not demonstrated in the study of Croy \& Kassouf (1989). There is therefore no evidence from the present study or that of Croy \& Kassouf (1989) that granulated metrial gland cells have NK activity, but failure to detect it could be due to technical factors.

Essentially all mechanically dissociated metrial gland cells bound to the NK target cell YAC-1 but not to adult thymocytes or P815 cells, which are resistant to NK lysis (Kiessling \& Wigzell, 1979; Wigzell \& Ramstedt, 1986). Some of the mechanically dissociated metrial gland cells might have been fibroblast-like stromal cells, but most appeared to be granulated cells because of the presence of small, PAS-positive granules within their vacuoles. Their expression of surface receptors for YAC-1 indicates that granulated metrial gland cells may be related in some way to NK cells. The latter are a somewhat diverse group whose lineage is not fully understood, but as a group they appear to be the only cells known to bind YAC-1 cells. The receptors for YAC-1 on granulated metrial gland cells were apparently degraded by collagenase and protease IX because enzymically dissociated, large, spherical cells bound only weakly to YAC-1 cells. The available evidence, including the presence of NK cells (Croy et al., 1985) and granulated metrial gland cells (Stewart \& Peel, 1981) in the mouse uterus during early pregnancy, tentatively suggests that granulated metrial gland cells may arise from NK cells that enter the uterus early in pregnancy and differentiate locally under the influence of steroid hormones, lymphokines, and/or other factors.

Enzymically dissociated, large, spherical cells progressively died in culture and failed to develop or regenerate cytoplasmic granules or surface receptors for YAC-1 cells. The culture medium we used has been widely used to maintain NK cells in vitro (Wiltrout $e t$ al., 1984), but it evidently lacks factors needed to support isolated granulated metrial gland cells. The lymphokines released by Con A-stimulated spleen cells had no effect on the large, spherical cells but further studies using specific lymphokines such as IL-2, which is essential for the maintenance of cloned NK cells in vitro (Born et al., 1983; Podack, 1985; Young et al., 1986), would be of interest. It is also possible that the isolated cells did poorly in culture because they were mainly mature granulated cells near the end of their period of differentiation in situ and had little capacity to repair cellular damage. There is morphological evidence that granulated cells die in the metrial gland (Bulmer et al., 1987), and if this is their normal fate it may be difficult to prolong their viability in vitro. The failure to develop cytoplasmic granules and surface receptors for YAC-I cells in culture was probably not due to inhibition by prostaglandin-secreting cells because indomethacin had no effect. Therefore, although enzymic dissociation of metrial glands provided large numbers of isolated, large, spherical cells, many of which appeared to be granulated metrial gland cells, the isolated cells suffered loss of granule content and damage to surface membrane constituents that were not reversed by a subsequent period of culture in vitro.

Stewart \& Mukhtar (1988) have provided a direct and elegant demonstration that granulated metrial gland cells are cytotoxic against a subpopulation of cells in placental cell cultures, using granulated effector cells that spontaneously migrated from metrial gland explants during culture in vitro, and which remained granulated. The exact nature of the target cells is not yet clear; they 
may be normal or abnormal trophoblast cells. Given the demonstrated cytotoxicity of granulated metrial gland cells and assuming that this activity may be expressed in vivo, information about the target cell specificity of granulated metrial gland cells is needed. For such studies the mechanically isolated metrial gland cells described in the present study may be useful because they appear to be mainly granulated cells and to retain surface receptors for target cells. Binding studies of the kind reported here, using the numerous lines of cultured trophoblast cells that have been described (Log et al., 1981; Hunt et al., 1989), some of which are oncogenic, would be of special interest because Stewart (1984) has demonstrated that mouse granulated metrial gland cells bound to layer 1 labryinthine trophoblast in vivo.

We thank Maureen Doran and Shonah Hunter for technical help. This work was supported by N.I.H. grant HD-17480.

\section{References}

Adam, E. \& Peel, S. (1983) The maintenance of rat metrial gland explants in vitro in the presence and absence of progesterone. J. Anat. 136, 321-328.

Born, W., Ben-Nun, A., Bamberger, U., Nakayama, M., Speth, V., Sun, D. \& Thornton, M. (1983) Killer-cell lines derived from mouse thymus resembling large granular lymphocytes and expressing natural killerlike cytotoxicity. Immunobiology 165, 63-77.

Bray, J., Stewart, I. \& Craggs, R. (1978) The demonstration of cells bearing $\mathrm{Fc}$ receptors in the metrial gland of the pregnant rat uterus. Cell Tiss. Res. 192, 89-96.

Bulmer, D., Peel, S. \& Stewart, I. (1987) The metrial gland. Cell Differentiation 20, 77-86.

Burton, R.C., Koo, G.C., Smart, Y.C., Clark, D.A. \& Winn, H.J. (1988) Surface antigens of murine natural killer cells. Int. Rev. Cytol. 111, 185-210.

Croy, B.A. \& Kassouf, S.A. (1989) Evaluation of the murine metrial gland for immunological function. $J$. Reprod. Immunol. 15, 51-69.

Croy, B.A., Gambel, P., Rossant, J. \& Wegmann, T.G. (1985) Characterization of murine decidual natural killer (NK) cells and their relevance to the success of pregnancy. Cell. Immunol. 93, 315-326.

Daki, N.M., Stewart, I.J. \& Wild, A.E. (1988) Fc $\gamma$ receptors on mouse metrial gland cells. Am. J. Reprod. Immunol. Microbiol. 16, 104, abstr.

Herberman, R.B. (1982) Natural killer cells and their possible relevance to transplantation biology. Transplantation 34, 1-7.

Hunt, J.F., Deb, S., Faria, P., Wheaton, D. \& Soares, M.J. (1989) Isolation of phenotypically distinct trophoblast cell lines from normal rat chorioallantoic placentas. Placenta (in press).

Kiessling, R. \& Wigzell, H. (1979) An analysis of the murine NK cell as to structure, function, and biological relevance. Immunol. Rev. 44, 165-208.

Log, T., Chang, K.S.S. \& Hsu, Y.C. (1981) Carcinomas induced by cell lines cultivated from normal mouse placentas. Int. J. Cancer 27, 365-372.

Matthews, C.J. \& Searle, R.F. (1986) The role of prostaglandins in the immunosuppressive effects of supernatants from adherent cells of murine decidual tissue. J. Reprod. Immunol. 12, 109-124.

Mitchell, B.S. \& Peel, S. (1984) Identification of cells bearing leucocyte surface antigens in metrial gland tissue from rats of different gestational ages, strains or parities. Immunology 53, 63-68.

Mukhtar, D.D.Y. \& Stewart, I. (1988) Migration of granulated metrial gland cells from cultured explants of mouse metrial gland tissue. Cell Tiss. Res. 253, $413-417$.

Ortaldo, J.R. \& Herberman, R.B. (1984) Heterogeneity of natural killer cells. Ann. Rev. Immunol. 2, 359-379.

Parr, E.L., Parr, M.B. \& Young, J.D-E. (1987) Localization of a pore-forming protein (perforin) in granulated metrial gland cells. Biol. Reprod. 37, 1327-1335.

Peel, S. \& Bulmer, D. (1977) The fine structure of the rat metrial gland in relation to the origin of the granulated cells. J. Anat. 123, 687-697.

Peel, S. \& Stewart, I. (1984) The differentiation of granulated metrial gland cells in chimeric mice and the effect of uterine shielding during irradiation. $J$. Anat. 139, 593-598.

Peel, S., Stewart, I. \& Bulmer, D. (1983) Evidence for the bone marrow origin of granulated metrial gland cells of the mouse. Cell Tiss. Res, 233, 647-656.

Podack, E.R. (1985) The molecular mechanism of lymphocyte-mediated tumor cell lysis. Immunol. Today 6, 21-27.

Reynolds, C.W., Timonen, T. \& Herberman, R.B. (1981) Natural killer (NK) cell activity in the rat. I. Isolation and characterization of the effector cells. J. Immunol. 127, 282-287.

Ritson, A. \& Bulmer, J.N. (1987) Endometrial granulocytes in human decidua react with a natural killer (NK) cell marker, NKHI. Immunology 62, 329-331.

Smith, L.J. (1966) Metrial gland and other glycogen containing cells in the mouse uterus following mating and through implantation of the embryo. Am. J. Anat. 119, 15-24.

Stewart, I. (1984) A morphological study of granulated metrial gland cells and trophoblast cells in the labyrinthine placenta of the mouse. J. Anat. 139, 627-639.

Stewart, I. \& Mukhtar, D.D.Y. (1988) The killing of mouse trophoblast cells by granulated metrial gland cells in vitro. Placenta $9,417-425$.

Stewart, I. \& Peel, S. (1977) The structure and differentiation of granulated metrial gland cells of the pregnant mouse uterus. Cell Tiss. Res. 184, 517-527. 
Stewart, I. \& Peel, S. (1981) Granulated metrial gland cells in the virgin and early pregnant mouse uterus. $J$. Anat. 133, 535-541.

Watson, J., Gills, S., Marbrook, J., Mochizuki, D. \& Smith, K.A. (1979) Biochemical and biological characterization of lymphocyte regulatory molecules. $J$. exp. Med. 150, 849-859.

Wigzell, H. \& Ramstedt, U. (1986) Natural killer cells. In Handbook of Experimental Immunology pp. 60.160.11. Ed. D. M. Weir. Blackwell Scientific Publications, London.

Wiltrout, R.H., Mathieson, B.J., Talmadge, J.E., Reynolds, C.W., Zhang, S., Herberman, R.B. \&
Ortaldo, J.R. (1984) Augmentation of organ-associated natural killer activity by biological response modifiers. Isolation and characterization of large granular lymphocytes from liver. J. exp. Med. 160, 1431-1437.

Young, J.D-E. \& Cohn, Z.A. (1986) Cell-mediated killing: a common mechanism. Cell 46, 641-642.

Young, J.D-E., Hengartner, H., Podack, E.R. \& Cohn, Z.A. (1986) Purification and characterization of a cytolytic pore-forming protein from granules of cloned lymphocytes with natural killer activity. Cell 44, 849-859.

Received 8 May 1989 